\title{
Analisis pelaksanaan layanan konseling pranikah dalam meminimalisir perceraian di Kantor Urusan Agama Kambu Kota Kendari
}

\author{
Heti Juningsih ${ }^{1)}$, Khairunnisa Syamsu ${ }^{2^{*}}$ \\ 1,2) IAIN Kendari \\ *) khairunnisa.syamsu@gmail.com
}

\author{
Article History: \\ Received: 04/09/2021; \\ Revised: 14/09/2021; \\ Accepted: 13/10/2021 \\ Published: 30/10/2021.
}

How to cite: Juningsih, H., \& Syamsu, K. (2021). Analisis pelaksanaan layanan konseling pranikah dalam meminimalisir perceraian di Kantor Urusan Agama Kambu Kota Kendari. Orien: Cakrawala Ilmiah Mahasiswa, 1(2), pp. 95-104. DOI 10.30998/ocim.v1i2.6057

(c) (i) This is an open distributed under the Creative Commons 4.0 Attribution License, which permits unrestricted use, distribution, and reproduction in any medium, provided the original work is properly cited. (C) 2021, Juningsih \& Syamsu.

\begin{abstract}
Abstrak: Penelitian ini untuk mengetahui layanan konseling pranikah dalam meminimalisir perceraian di Kantor Urusan Agama (KUA) Kecamatan Kambu Kota Kendari. Penelitian ini menganalisis peran penyuluh agama dalam meminimalisir perceraian di KUA Kecamatan Kambu, strategi bimbingan konseling pranikah dalam meminimakisir perceraian di KUA Kecamatan Kambu, dan kendala-kendala yang dihadapi dalam melaksanakan bimbingan konseling pranikah untuk meminimalisir perceraian di KUA Kecamatan Kambu. Penelitian ini merupakan penelitian deskriptif dengan pendekatan kualitatif. Data dikumpulkan dengan wawancara mendalam dengan narasumber, studi dokumentasi, dan pengamatan langsung (observasi) terkait dengan pelaksanaan konseling keluarga di KUA Kecamatan Kambu Kota Kendari. Adapun manfaat yang akan dicapai dari penelitian ini sebagai kontribusi pemikiran dan ikut memperluas wacana keilmuan, khususnya mengenai pelaksanaan bimbingan konseling pranikah sebagai di KUA Kecamatan Kambu Kota Kendari.
\end{abstract}

Kata Kunci: konseling pranikah, perceraian

\begin{abstract}
This study aims to determine the pre-marital counseling guidance service (to minimizing divorce in KUA Kambu District, Kendari City. This study will analyze the role of religious instructors in minimizing divorce in KUA Kambu District, counseling guidance strategies in minimizing divorce in Kambu District KUA, and the constraints). the obstacles faced in carrying out premarital counseling guidance to avoid divorce at KUA District Kambu. This research is a descriptive qualitative approach. Data collected by in-depth interviews with resource persons, documentation studies, and direct observations related to the implementation of family counseling at the KUA Kambu District, Kendari City. as in KUA Kambu District, Kendari City.
\end{abstract}

Keywords: premarital counseling, divorce

\section{Pendahuluan}

Perkawinan atau pernikahan memiliki tujuan membentuk keluarga (rumah tangga) yang bahagia dan kekal berdasarkan Ketuhanan Yang Maha Esa. Hal ini sesuai dengan rumusan yang terkandung dalam Undang-Undang Nomor 1 tahun 1974 pasal 1 bahwa: "Perkawinan merupakan ikatan lahir dan batin antara seorang wanita dengan seorang pria sebagai suami istri dengan tujuan membentuk keluarga (rumah tangga) yang bahagia dan kekal berdasarkan Ketuhanan Yang Maha Esa" (Walgito, 2017). Pernikahan merupakan peristiwa penting dalam hidup seseorang dan diharapkan terjadi sekali seumur hidup, sehingga perlu dipersiapkan 
sebaik dan sematang mungkin. Pernikahan merupakan sesuatu yang sakral dengan tujuan yang sakral pula. Pernikahan dilangsungkan bukan semata-mata untuk memuaskan nafsu birahi, melainkan untuk memperoleh ketenteraman dan kedamaian jiwa, saling mengasihi, menyayangi serta saling mengayomi diantara suami istri. Namun pada kenyataannya menunjukkan bahwa membangun mahligai rumah tangga bukanlah perkara yang mudah, butuh kerja sama diantara suami istri untuk membina dan memelihara hubungan rumah tangganya sehingga bisa mencapai kedamaian dan kesejahteraan yang disebut dengan keluarga sakinah. Data yang diperoleh bahwa Pengadilan Agama Kota Kendari mencatat kasus perceraian selama 2021 mencapai 805 kasus. Dari 805 kasus tersebut terdapat 637 kasus yang sudah diputuskan atau resmi bercerai, dan 478 kasus diantaranya digugat oleh pihak istri. Dari kasus yang ditangani Pengadilan Agama itu, kebanyakan karena faktor perselisihan dalam rumah tangga (May, 2021).

Kenyataan tersebut menyadarkan akan perlunya calon pasangan suami istri untuk mempersiapkan dengan baik rumah tangganya, salah satu upaya yang bisa dilakukan melalui konseling pranikah. Konseling pranikah merupakan upaya profesional yang dilaksanakan dalam rangka membantu calon pasangan suami istri agar dapat sama-sama berkembang dan mampu mencegah serta menyelesaikan konflik-konflik rumah tangga yang terjadi dengan cara saling menghargai, toleransi, komunikasi yang penuh pengertian, sehingga mencapai kesejahteraan dan keharmonisan di dalam rumah tangganya.

Pemerintah melalui Kementerian Agama telah memprogramkan aspek bimbingan dan konseling pada setiap unit layanannya yang terdapat pada Kantor Urusan Agama (KUA). Bimbingan tersebut diberikan baik untuk menghindari kesulitan-kesulitan maupun untuk mengatasi persoalan-persoalan yang dihadapi oleh individu didalam kehidupan bermasyarakat. Bimbingan dimaksudkan supaya individu atau sekumpulan individu mencapai kesejahteraan hidup (life welfare). Disinilah letak bimbingan yang sebenarnya (Walgito, 2010). Adapun konseling merupakan bantuan yang diberikan kepada konseli dalam memecahkan masalahmasalah kehidupan dengan wawancara yang dilakukan secara face to face, atau dengan cara-cara yang sesuai dengan keadaan konseli yang dihadapi untuk mencapai kesejahteraan hidupnya (Rozikan, 2017).

Kantor Urusan Agama sebagai salah satu lembaga yang berada di bawah naungan Kementerian Agama di dalamnya terdapat penyuluh agama Islam yang bertugas dalam memberikan layanan bimbingan dan konseling, termasuk bimbingan konseling pranikah. KUA berperan aktif dalam kegiatan bimbingan konseling pranikah. Bimbingan konseling pranikah merupakan kegiatan yang diselenggarakan kepada pihak-pihak yang belum menikah, sehubungan dengan rencana pernikahannya. Pihak-pihak tersebut datang ke konselor untuk membuat keputusannya agar lebih mantap dan dapat melakukan penyesuaian di kemudian hari secara baik (Hidayah, 2021). Konseling pernikahan atau yang biasa disebut marriage counseling merupakan upaya membantu pasangan calon pengantin. Tujuannya agar mereka dapat berkembang dan mampu memecahkan masalah yang dihadapinya melalui cara-cara yang saling menghargai, toleransi, dan komunikasi, agar dapat tercapai motivasi berkeluarga, perkembangan, kemandirian, dan kesejahteraan seluruh anggota keluarganya (Willis, 2016).

Menurut (Karim, 2020) bimbingan pranikah ialah pemberian bekal pengetahuan, pemahaman, dan keterampilan dalam waktu singkat kepada calon suami istri tentang kehidupan rumah tangga atau keluarga. Jadi, yang dimaksud dengan bimbingan pranikah dalam penelitian ini adalah pemberian materi-materi atau pembekalan pengetahuan tentang berbagai seluk beluk pernikahan yang diberikan sebelum proses akad nikah berlangsung. Adapun tahapan yang dilakukan berupa tahap awal atau permulaan, tahap berlangsung dan tahap berakhirnya suatu kegiatan penasehat atau pembekalan pernikahan. 
Penyuluh agama mempunyai tiga fungsi yaitu fungsi informatif edukatif, fungsi konsultatif, dan fungsi advokatif. Fungsi edukatif dilaksanakan melalui layanan bimbingan, sedangkan fungsi konsultatif dan advokatif bisa dilaksanakan melalui layanan konseling. Penyuluh agama harus bisa menjadi penyelesai semua masalah umat, harus menjalankan fungsi konsultatif dan advokatif, mengingat problem masyarakat yang muncul semakin banyak dan bervariasi, khususnya problem perceraian (Jaya, 2017). Keterlibatan penyuluh agama Islam dalam layanan bimbingan konseling pranikah sangat dibutuhkan sebagai salah satu upaya untuk meminimalisir kasus perceraian yang terus mengalami peningkatan. Pemberian bimbingan pranikah sebagai sesuatu yang urgen untuk dilakukan. Urgensi bimbingan pranikah adalah pemberian bekal pengetahuan, pemahaman, keterampilan dan pertumbuhan kesadaran kepada remaja usai nikah dan calon pengantin tentang kehidupan rumah tangga dan keluarga (Ridho, 2018).

Penyuluh agama memiliki tugas yang signifikan untuk mencegah dan meminimalisir terjadinya perceraian di dalam rumah tangga. Hal tersebut merupakan tugas yang paling besar untuk seorang penyuluh agama, karena dalam perannya tersebut, penyuluh agama bertugas untuk mencegah adanya perceraian dan melindungi pernikahan agar sesuai dengan tujuan pernikahan. Peranan seorang penyuluh agama dalam memberikan bimbingan konseling pra nikah diharapkan dapat membantu dan mengarahkan calon pengantin untuk bekal pernikahannya di masa yang akan datang sebagai bekal untuk mewujudkan keluarga yang sakinah, mawaddah, dan warrahmah.

Hasil penelitian (Munir, 2019) menyatakan bahwa penyuluh agama di KUA diharapkan mampu menjadi mediasi dalam mencapai tujuan pernikahan. Salah satu peran penyuluh agama di KUA adalah mengupayakan untuk mencegah terjadinya perceraian. Kedudukan penyuluh agama di tengah masyarakat ini sangatlah penting dan perannya cukup besar terhadap perceraian di KUA Dawe dalam mengatasi permasalahan suami istri, sedangkan angka perceraian di Kecamatan Dawe bisa dikatakan meningkat dengan adanya pernikahan yang tinggi, dalam hal itu penyuluh agama juga berperan aktif dalam pembinaan masyarakat dengan cara memberikan bimbingan pernikahan dengan menyelenggarakan kursus calon pengantin dan mengembangkan pembinaan keluarga sakinah. Penyuluh agama di KUA diharapkan mampu menjadi mediasi dalam persoalan- persoalan rumah tangga yang menjadikan tingginya angka perceraian di era sekarang ini. Dalam hal ini diharapkan peran dari seorang penyuluh dapat mengurangi tingkat perceraian yang dari tahun ke tahun semakin meningkat.

KUA Kecamatan Kambu juga diharapkan memiliki penyuluh agama Islam yang mumpuni dengan berbagai strategi dalam menekan kasus perceraian khususnya di kecamatan Kambu. Berdasarkan wawancara awal yang dilakukan pada staf administrasi KUA kecamatan Kambu menuturkan bahwa sejauh ini KUA Kecamatan Kambu melakukan bimbingan konseling pranikah dibawah bimbingan Divisi Keluarga Sakinah. Staf administrasi bertugas sebagai pengelola data dan administrasi KUA disini termasuk data pasangan yang akan menerima konseling pranikah yang dilakukan oleh divisi keluarga sakinah. Bimbingan konseling pranikah lebih dikenal dengan istilah kursus catin (kursus calon pengantin) dan ini dilakukan oleh kepala KUA, Penghulu, atau penyuluh agama keluarga sakinah dan diberikan kepada siapa saja yang mendaftar kan diri sebagai calon pengantin di kecamatan Kambu.

Melalui data awal yang diperoleh, dapat diketahui bahwa KUA Kecamatan Kambu telah melaksanakan layanan bimbingan konseling pranikah, maka penelitian ini bertujuan untuk menganalisis peran penyuluh agama sebagai pembimbing dan konselor pranikah di KUA Kecamatan Kambu dalam meminimalisir perceraian, strategi bimbingan konseling pranikah yang sudah dilaksanakan di KUA Kecamatan Kambu dalam meminimalisir perceraian, dan 
kendala-kendala yang dihadapi penyuluh agama di KUA Kecamatan Kambu dalam melaksanakan bimbingan konseling pranikah dalam meminimalisir perceraian di masyarakat. Hasil penelitian ini diharapkan dapat memperkaya khazanah ilmu pengetahuan bimbingan konseling khususnya dalam bidang bimbingan konseling pranikah serta menjadi referensi tambahan mengenai strategi pelaksanaan bimbingan konseling pranikah di masyarakat.

\section{Metode}

Penelitian ini menggunakan metode penelitian deskriptif kualitatif melalui. Penelitian ini dilaksanakan di Kantor Urusan Agama Kecamatan Kambu Kota Kendari. Waktu penelitian dilaksanakan pada Juli hingga September 2021, dengan total informan berjumlah dua orang yang terdiri dari penyuluh agama divisi keluarga sakinah dan penghulu KUA Kecamatan Kadia. Proses pengumpulan data dilakukan cara observasi, dokumentasi dan wawancara. Analisis data terdiri dari tahap pengumpulan data, tahap reduksi data, tahap penyajian data dan tahap penarikan kesimpulan.

\section{Hasil dan Diskusi}

\section{Peran penyuluh agama dalam meminimalisir perceraian di KUA Kecamatan Kambu}

Semakin tingginya angka perceraian dan semakin banyak masyarakat yang terjebak dengan permasalahan keluarga, sehingga layanan bimbingan konseling pranikah sangat dibutuhkan oleh masyarakat sebagai upaya preventif dan kuratif. Penyuluh Agama Islam memiliki peran yang strategis untuk mencegah terjadinya perceraian. Penyuluh diamanahkan untuk membekali setiap individu agar dapat memiliki persiapan mental dan fisik serta daya tahan yang kuat dalam menghadapi goncangan perkawinan.

Penyuluhan Agama Islam yang terdapat di Kantor Urusan Agama (KUA) setiap kecamatan di Indonesia bertugas memberikan penerangan seputar bimbingan perkawinan dan memberikan arahan tentang menjalin hubungan suami istri yang ideal. Selain bimbingan, penyuluh agama juga berperan memberikan konseling pra nikah. Konseling pra nikah dianggap penting karena awal terbinanya kehidupan rumah tangga sangat bergantung pada pembekalan awal sebelum calon pengantin melangsungkan pernikahan, tujuannya mempertinggi mutu perkawinan dengan mewujudkan keluarga sakinah. Penyuluh agama di Kantor Urusan Agama (KUA) harus melaksanakan fungsinya sebagai pembimbing dan konselor bagi masyarakat. Jika penyuluh agama bisa melaksanakan layanan bimbingan konseling pranikah, maka diharapkan bisa menekan angka perceraian di masyarakat.

Hasil wawancara dengan narasumber bapak Tugiman, S.Pd.I selaku Penyuluh Agama Keluarga Sakinah KUA Kecamatan Kambu, diungkapkan bahwa peran penyuluh agama dalam meminimalisir perceraian di KUA Kecamatan Kambu dilakukan melalui langkah-langkah preventif melalui kegiatan bimbingan pra-nikah. Bimbingan kepada catin (calon pengantin) diawali dengan penyaringan awal sebagai calon pengantin dan pemberian kursus calon pengantin (kurcatin). Penyuluh agama memberikan bimbingan dan pengarahan dalam bentuk sosialisasi kepada pemuda pemudi usia 19 tahun keatas, materi-materi bimbinan yang diberikan yaitu kewajiban antara istri dan suami, tujuan berkeluarga, bekal kehidupan berumah tangga, bekal menjadi orang tua, dan persiapan fisik, mental dan keagamaan sebelum berkeluarga.

Penyuluh agama KUA Kecamatan Kambu melaksanakan layanan informatif dalam bentuk bimbingan dan sosialisasi kepada para remaja dan calon pengantin mengenai berbagai materi-materi yang berkaitan dengan persiapan hidup berkeluarga. Diharapkan dengan bekal 
pemahaman yang baik mengenai kehidupan berkeluarga, dapat mencegah terjadinya perceraian ketika nantinya menjalani mahligai pernikahan. Langkah-langkah konseling juga telah dilaksanakan secara face to face (tatap muka) antara penyuluh agama dengan calon pesangan suami istri. Calon pasangan suami istri datang ke KUA dan mendapatkan konseling seputar pernikahan, dalam proses ini diharapkan tidak hanya diikuti oleh calon suami istri akan tetapi juga dihadiri oleh orang tua dan calon mertua. Hal ini dilakukan agar tidak terjadi apriori (orang tua tidak lepas tangan ketika terjadi permasalahan dalam kehidupan rumah tangga anak). Diharapkan ketika terjadi konflik dalam rumah tangga anaknya orang tua tidak mengatakan "itukan pilihan kamu" atau bahasa lain menolak tanggung jawabnya sebagai orang tua, orang tua cenderung beranggapan diawal pernikahan bahwa pilihan anak adalah pilihan yang terbaik, padahal pilihan terbaik pun tetap memerlukan bimbingan orang tua.

Orang tua memiliki tugas untuk memilihkan jodoh untuk anaknya mulai dari karakter, kesholihannya, kepatuhannya terhadap ketaatannya kepada Allah dan kepada manusia, sehingga orang tua dan mertua juga berperan penting dalam keberlangsungan hidup rumah tangga. Namun pendekatan seperti ini masih jarang dilaksanakan di KUA, khususnya di KUA Kecamatan Kambu.

Selain langkah-langkah pencegahan yang telah dipaparkan di atas, upaya untuk mengentaskan masalah dalam bentuk konseling telah dilaksanakan namun belum optimal. Narasumber menuturkan, kebanyakan pasangan suami istri yang akan bercerai, mengadukan persoalan rumah tangganya ke orang tua, lalu orang tua datang ke KUA untuk menanyakan proses gugat cerai ke pengadilan. KUA tidak mengupayakan jalan damai agar permasalahan yang dialami pasangan suami istri tidak berlanjut ke meja pengadilan. Mestinya KUA sebagai lapisan terbawah dalam memberikan layanan bimbingan pernikahan di masyarakat, perlu mengadakan langkah-langkah solutif sebelum konflik sampai dimeja hijau. KUA menjadi tempat untuk berkonsultasi atas permasalahan yang mereka hadapi dengan harapan benang yang kusut dan terpintal bisa ditarik dan teruai kembali dengan tujuan mencari solusi dari masalah yang dihadapi.

Langkah konseling keluarga dengan melibatkan orang tua dan mertua juga perlu dilakukan untuk mencari solusi bersama. Sesuai dengan uraian sebelumnya, bahwa kehidupan berumah tangga merupakan tanggung jawab bersama yakni pasangan suami istri, orang tua dan mertua. Namun yang terjadi di KUA Kecamatan Kambu, orang tua pasangan suami istri yang mengalami konflik hanya mengambil langkah akhir, begitu pula pasangan suami istri yang ingin bercerai cenderung menginginkan agar cepat berpisah, tanpa terlebih dahulu melalui proses konseling untuk mencari langkah-langkah yang mungkin bisa dilakukan agar perceraian tidak terjadi.

Berdasarkan temuan penelitian tersebut, dapat dipahami bahwa peran informatifedukatif dalam bentuk sosialisasi dan bimbingan mendominasi dalam upaya KUA Kecamatan Kambu untuk meminimalisir perceraian. Sedangkan fungsi konsultatif dan advokatif belum banyak dilakukan. Menurut (Jaya, 2017) bahwa kedua peran tersebut sangat penting dan mendesak mengingat masalah sosial di masyarakat semakin banyak. Fungsi konsultatif adalah peran penyuluh agama untuk memberikan solusi atas masalah yang dihadapi umat, terutama memberi bimbingan dan konseling atas persoalan hidup yang masyarakat alami (problem solver).

\section{Strategi konseling pranikah dalam meminimalisir perceraian di KUA Kecamatan Kambu}

Strategi bimbingan konseling pranikah yang dilaksanakan di KUA Kecamatan Kambu dapat dikatakan cukup baik, karena program yang ada dijalankan sesuai dengan rencana yang 
telah disusun sebelumnya. Sesuai paparan sebelumnya, bahwa KUA Kecamatan Kambu melaksanakan layanan bimbingan konseling pranikah dalam bentuk sosialisasi dan kursus calon pengantin (SUSCATIN) bagi calon pengantin (catin). SUSCATIN merupakan singkatan dari Kursus Calon Pengantin atau yang sering disebut dengan konseling pranikah. Sedangkan pengertian dari Konseling pranikah adalah pelatihan berbasis pengetahuan dan keterampilan yang menyediakan informasi mengenai pernikahan yang dapat bermanfaat untuk mempertahankan dan meningkatkan hubungan pasangan yang akan menikah (Anisa \& Ningsih, 2016).

Adapun tujuan dari konseling pranikah yakni 1) membantu pasangan calon pengantin untuk mengerti makna dari pernikahan, 2) membantu pasangan calon pengantin membangun pondasi kuat dan menyelaraskan tujuan dalam membentuk rumah tangganya, 3) membantu pasangan calon pengantin untuk mengerti peran serta fungsi masing-masing antara suami dan istri, 4) membantu calon pengantin untuk mempersiapkan dirinya menjelang pernikahan meliputi fisik, psikologis dan spiritual (Mariamah, 2020).

Berdasarkan hasil wawancara dengan narasumber bapak Tugiman, S.Pd.I selaku Penyuluh Agama Keluarga Sakinah KUA Kecamatan Kambu bahwa ada beberapa langkah yang diterapkan oleh para penyuluh dalam melakukan bimbingan konseling pranikah di lapangan. Adapun langkah yang dilakukan yaitu :

1. pendataan awal, untuk melihat latar belakang konseli yang dimulai dari pendidikan, termasuk pengetahuan agamanya secara umum.

2. menyampaikan maksud utama kegiatan bimbingan konseling pranikah kepada konseli dalam hal ini konselinya adalah calon pengantin (catin). Menyampaikan bahwa kegiatan tersebut bertujuan untuk menciptakan kelanggengan dalam kehidupan rumah dan tentunya tentang kasus-kasus yang terjadi yang menjadi sebab tidak rukunnya rumah tangga.

3. Jika catin sangat minim pemahaman agamanya maka penyuluh agama memberikan pengetahuan seputar agama yang dasar dulu, secara umum untuk mereka yang sudah memiliki pemahaman yang baik maka tidak dilalukan SUSCATIN, namun jika mereka bersedia maka kami akan tetap memberikan SUSCATIN akan tetapi arahnya bukan pada pemberian pemahaman agama melainkan lebih kepada kesiapan dalam berumah tangga, seperti pergaulan suami istri, bagaimana kondisi suami dan kesiapan-kesiapan dalam menghadapi masalah rumah tangga yang ini musti terjadi dalam kehidupan manusia sehingga bisa terwujud keluarga yang sakinah, mawadah warahmah.

Secara rinci, bentuk-bentuk strategi bimbingan pranikah yang telah dilaksanakan di KUA Kecamatan Kambu yaitu :

1. Bimbingan Klasikal, adalah program yang dirancang menuntut konselor untuk melakukan kontak langsung dengan para peserta catin. Secara terjadwal, konselor memberikan pelayanan bimbingan kepada para CATIN.

2. Metode Permainan, itu metode dengan melakukan permainan sehingga dapat mendukung perkembangan interpersonal dan intrapersonal CATIN. Ada nya konselor dapat membantu calon pengantin untuk mengembangkan hal-hal yang positif.

3. Metode diskusi, adalah suatu kegiatan yang dilakukan dalam suasana kelompok dimana didalamnya terdapat guru pembimbing/konselor sebagai pemimpin kelompok dan anggota kelompok yang memiliki kesempatan yang sama untuk menyumbangkan pikirannya atau ide-ide dan pendapat yang dimilikinya dalam memecahkan masalah bersifat umum yang menjadi topik pembahasan. 
4. Sosialisasi dilapangan, namun ini sangat jarang kami lakukan karena mengingat begitu banyaknya pernikahan yang kami tangani sehingga waktu untuk turun lapangan sosialisasi sangat sedikit.

Narasumber bapak Tugiman, S.Pd.I selaku Penyuluh Agama Keluarga Sakinah KUA Kecamatan Kambu menuturkan bahwa dari ketiga strategi di atas sebenarnya semua sudah ada didalam modul panduan pelaksanaan bimbingan pranikah dari Kementerian agama, akan tetapi selama ini KUA Kecamatan Kambu hanya menggunakan bentuk-bentuk klasikal karena dirasa paling efesien, terkadang juga menyesuaikan dengan jadwal calon pengantin jika ada yang menikah dibulan yang sama maka akan menggabungkan dalam satu kegiatan bimbingan (bimbingan pranikah kelompok).

Sedangkan layanan konseling untuk masyarakat yang mengalami permasalahan keluarga, belum banyak ditangani secara khusus oleh KUA Kecamatan Kambu. Bantuan hanya diberikan bersamaan dengan kegiatan sosialisasi ataupun dirangkaikan dengan kegiatan kajian keagamaan. Kebanyakan masyarakat mengadukan masalahnya ketika sudah rumit atau ketika mereka ingin buka meja kepengadilan.

Padahal, semakin banyak permasalahan yang timbul dalam kehidupan baik pernikahan dan keluarga maka peran konselor dalam bidang bimbingan dan konseling sangat dibutuhkan, kegiatan layanan bimbingan dapat dilakukan dalam format bentuk kelompok ataupun klasikal sedangkan proses konseling face to face atau konseling individu guna untuk mencari jalan keluar terhadap permasalahan yang sedang dihadapi konseli sebagaimana yang dituntun oleh agama untuk memberikan arah, jalan dan petunjuk kepada individu yang membutuhkan juga sangat perlu diberikan (Wulan, 2021).

\section{Kendala-kendala dalam melaksanakan konseling pranikah dalam meminimalisir perceraian di KUA Kecamatan Kambu}

KUA sebagai lapisan terbawah di masyarakat harus turut andil dalam menyelesaikan permasalah keluarga, fungsi konseling di KUA perlu dihidupkan. Dalam praktiknya jarang sekali penyuluh agama yang memainkan peran sebagai konselor. Hal ini terjadi karena Kantor Urusan Agama (KUA) di kecamatan tidak mempromosikan peran konsultatif sehingga tidak ada klien yang datang untuk menyampaikan persoalan yang mereka hadapi. Hal ini juga didasarkan pada fasilitas KUA yang belum mempunyai ruang konseling yang memadai. Padahal jika memeriksa banyaknya kasus atau masalah sosial yang ada di masyarakat harusnya banyak orang yang dapat memanfaatkan konseling di KUA. masyarakat belum percaya atau belum membuktikan bahwa pergi ke KUA dapat menyelesaikan masalah. Jika fungsi konselor telah berjalan dengan baik maka ketika masyarakat punya masalah secara otomatis pikirannya akan langsung tertuju ke KUA (Jaya, 2017).

Kenyataan ini juga terjadi di KUA Kecamatan Kambu, pendekatan konseling sudah ada dan sudah dilaksanakan tapi belum maksimal, karena belum ada tenaga ahli menangani hal tersebut. Narasumber menuturkan penyuluh agama disana sangat sibuk untuk menangani masyarakat yang mengajukan pernikahan, sedangkan layanan konseling untuk mencegah kasus perceraian kurang medapatkan penanganan. Hal ini dikarenakan kasus perceraian perlu ditangani secara khusus dan memerlukan penanganan lebih lama, selain itu belum ada penyuluh agama yang secara khusus bertugas untuk melaksanakan layanan konseling pernikahan di KUA. Idealnya di setiap KUA ada penyuluh agama yang khusus memberikan layanan konseling.

Narasumber bapak Tugiman, S.Pd.I selaku Penyuluh Agama Keluarga Sakinah KUA Kecamatan Kambu menuturkan bahwa, sampai saat ini belum ada masyarakat yang secara 
khusus datang untuk mendapatkan layanan konseling dalam mengatasi perceraian, KUA Kecamatan Kambu kekurangan tenaga ahli yang khusus melaksanakan layanan konseling dan juga waktu yang begitu terbatas dalam menangani kasus perceraian, kebanyakan masyarakat mengadukan masalahnya ketika sudah rumit atau ketika mereka ingin buka meja ke pengadilan.

Narasumber juga mengungkapkan bahwa kendala yang dihadapi sehingga tidak maksimal dalam melakukan layanan konseling pranikah dalam meminimalisir perceraian karena SDM KUA Kecamatan Kadia tidak memiliki kapasitas dalam konseling dan belum adanya bidang khusus di KUA Kecamatan Kadia yang memiliki keahlian dalam bidang bimbingan konseling, mereka menuturkan ini satu hal perlu dikaji oleh pemerintah pusat untuk menyediakan bidang khusus di KUA Kecamatan Kadia yang menangani hal ini. Penyuluh di KUA Kecamatan Kadia beranggapan tidak memiliki kapasitas dan keahlian dalam memberikan layanan konseling di KUA. Dari temuan di lapangan ini, muncul pertanyaan "siapakah konselor itu? Apakah penyuluh agama di KUA memiliki kapasitas untuk memberikan layanan konseling kepada masyarakat?. Sebagai sebuah profesi, konselor adalah tenaga profesional yang memiliki keahlian dalam pelayanan konseling. Menurut konsep counseling for all, yaitu konseling untuk masyarakat luas, di dalamnya konseling terdapat kegiatan bimbingan (guidance). Konselor sebagai tenaga profesional dalam bidang bimbingan dan konseling harus memiliki sertifikasi dan lisensi untuk menyelenggarakan layanan profesional bagi masyarakat (Habsy, 2017).

Konselor sebagai tenaga helper yang memberikan pertolongan kepada individu baik yang memiliki masalah ataupun yang tidak memiliki masalah. Dengan berpegang teguh kepada ajaran Islam maka sarjana agama sebagai salah satu konselor islam terutama di kantor urusan agama yang mengembangkan keahliannya sebagai konselor di bidang agama dalam memberikan bimbingan dan konseling baik untuk calon pengantin (sepasang kekasih) maupun kepada keluarga (suami istri) yang memiliki problem (Wulan, 2021).

Salah satu bentuk bimbingan konseling adalah religious guidance (bimbingan keagamaan) yaitu bimbingan dalam rangka membantu pemecahan masalah seseorang dalam kaitannya dalam masalah keagamaan, melalui keimanan menurut agamanya. Dengan menggunakan pendekatan bimbingan keagaman tersebut invidu dapat diberi insight (kesadaran terhadap adanya hubungan sebab terkait dengan masalah yang dihadapinya (Daulay, 2018). Sehingga dapat ditarik kesimpulan bahwa penyuluh agama di KUA juga memiliki peranan sebagai konselor bagi masyarakat, tentunya dengan pendekatan keagamaan.

Kebutuhan akan layanan konseling Islam di masyarakat juga sangat dirasakan, khususnya oleh penyuluh agama di KUA Kecamatan Kambu. Narasumber Bapak Abdul Syukur, S.Ag. selaku penghulu agama KUA Kecamatan Kambu menyatakan bahwa akan sangat tepat kalau di KUA Kecamatan Kambu ada layanan konseling Islam, sehingga keluarga yang bermasalah bisa ditangani langsung oleh ahlinya. Konseling Islam adalah suatu usaha pemberian bantuan kepada individu yang mengalami kesulitan rohaniah baik mental dan spiritual agar yang bersangkutan mampu mengatasinya dengan kemampuan yang ada pada dirinya sendiri melalui dorongan dari kekuatan iman dan ketakwaan kepada Allah SWT (Kadafi, 2016).

KUA Kecamatan Kambu telah memberikan pelayanan bimbingan konseling pranikah akan tetapi tidak maksimal mengingat tenaga yang terbatas dan sedangkan jumlah tanggung jawab yang harus diselesaikan tidak sebanding, sehingga KUA sibuk menikahkan dan mengurus hal hal yang berkaitan persiapan pernikahan sehingga pelayanan dalam penyelesaian konfik sangat minim. Sosialisasi dan bimbingan pranikah dilapangan juga jarang dilakukan karena mengingat begitu banyaknya pernikahan yang ditangani sehingga waktu untuk turun lapangan sangat sedikit. Narasumber juga menuturkan bahwa ada modul yang disediakan oleh kementerian agama terkait bimbingan konseling pranikah, akan tetapi KUA Kecamatan Kadia 
tidak terfokus pada modul yang ada karena melihat kondisi lapangan dan menyesuaikan dengan kondisi yang ada. Hambatan lainnya yaitu kondisi calon pengantin yang minim akan kesadaran beribadah $(80 \%$ tidak melaksanakan sholat), sehingga sulit menjelaskan hak-hak dan kewajibannya terhadap istri atau suaminya, sehingga terlebih dahulu difokuskan pada penanaman pemahaman agama nya.

Berdasarkan hasil pengolahan data dapat disimpulkan bahwa kendala-kendala dalam melaksanakan konseling pranikah dalam meminimalisir perceraian di KUA Kecamatan Kambu, yaitu : 1) terbatasnya SDM yang profesional di KUA Kecamatan Kambu, 2) Belum adanya tenaga profesional di KUA Kecamatan Kambu yang secara khusus melaksanakan layanan bimbingan konseling pranikah, dan 3) Masyarakat belum menyadari arti pentingnya konseling pranikah.

\section{Simpulan}

Berdasarkan hasil penelitian mengungkapkan bahwa peran penyuluh agama dalam meminimalisir perceraian di KUA Kecamatan Kambu telah dilakukan melalui langkah-langkah preventif melalui kegiatan bimbingan pranikah. Penyuluh agama KUA Kecamatan Kambu melaksanakan layanan informasi dalam bentuk bimbingan dan sosialisasi kepada para remaja dan calon pengantin mengenai berbagai materi-materi yang berkaitan dengan persiapan hidup berkeluarga. Adapun bentuk-bentuk strategi bimbingan pranikah yang telah dilaksanakan di KUA Kecamatan Kambu yaitu bimbingan klasikal, metode permainan, metode diskusi, dan sosialisasi di lapangan.

Dalam hal pengentasan masalah perceraian, layanan informatif-edukatif dalam bentuk sosialisasi dan bimbingan mendominasi. Fungsi konsultatif dan advokatif belum banyak dilakukan. Pemahaman penyuluh mengenai konsep konseling pun terbatas sehingga dibutuhkan pembekalan kompetensi dalam hal bimbingan konseling, termasuk konseling pranikah.

Layanan konseling untuk masyarakat yang mengalami permasalahan keluarga, belum banyak ditangani secara khusus oleh KUA Kecamatan Kambu. Kebanyakan masyarakat mengadukan masalahnya ketika sudah rumit atau ketika mereka ingin buka meja ke pengadilan (ingin bercerai di pengadilan). Kendala-kendala dalam melaksanakan konseling pranikah dalam meminimalisir perceraian di KUA Kecamatan Kambu, yaitu: 1) terbatasnya SDM yang profesional di KUA Kecamatan Kambu, 2) belum adanya tenaga profesional di KUA Kecamatan Kambu yang secara khusus melaksanakan layanan bimbingan konseling pranikah, dan 3) masyarakat belum menyadari arti pentingnya konseling pranikah.

\section{Ucapan Terima Kasih}

Penulis mengucapkan terimakasih kepada orang tua, keluarga, kepala KUA, Penyuluh agama divisi keluarga sakinah dan penghulu agama KUA Kecamatan Kambu Kota Kendari dan semua pihak yang telah mendukung terwujudnya artikel ini.

\section{Daftar Rujukan}

Anisa, L. S., \& Ningsih, Y. (2016). Efektifitas SUSCATIN (Kursus Calon Pengantin) dalam Membentuk Keluarga Bahagia. Jurnal Bimbingan Dan Konseling Islam, Http://Jurnalbki. Uinsby. Ac. Id. Phx/Jurnalbki/Article/View/48, 1. 
Daulay, M. (2018). Urgensi Bimbingan Konseling Islam Dalam Membentuk Mental Yang Sehat. Hikmah, 12(1), 146-159.

Habsy, B. A. (2017). Filosofi Ilmu Bimbingan Dan Konseling Indonesia. JP (Jurnal Pendidikan): Teori Dan Praktik, 2(1), 1-11.

Hidayah, A. N. (2021). Bimbingan Pranikah Dalam Upaya Membangun Ketahanan Keluarga Penelitian Di Kua Kecamatan Ciparay. UIN Sunan Gunung Djati Bandung.

Jaya, P. H. I. (2017). Revitalisasi Peran Penyuluh Agama Dalam Fungsinya Sebagai Konselor Dan Pendamping Masyarakat. KONSELING RELIGI: Jurnal Bimbingan Konseling Islam, 8(2).

Kadafi, A. (2016). Urgensi Konseling Islami Dalam Layanan Konseling Di Era Masyarakat Ekonomi Asean. Proceedings International Seminar FoE (Faculty of Education), 209-219.

Karim, H. A. (2020). Manajemen Pengelolaan Bimbingan Pranikah Dalam Mewujudkan Keluarga Sakinah Mawaddah Wa Rahmah. Jurnal Bimbingan Penyuluhan Islam, 1(2), 321-336.

Mariamah, M. (2020). Konseling pranikah dalam meningkatkan kematangan psikologi calon pengantin studi kasus KUA Kecamatan Batulayar TA 2019/2020. UIN Mataram.

May, A. (2021). Waduh, 637 Pasutri di Kendari Cerai dalam Waktu 10 Bulan. Retrieved from telisik.id website: https:/telisik.id/news/waduh-637-pasutri-di-kendari-cerai-dalamwaktu-10-bulan

Munir, M. (2019). Peran Penyuluh Agama Dalam Mengurangi Tingkat Perceraian Di Kua Kecamatan Dawe Kebupaten Kudus Tahun 2018. IAIN KUDUS.

Ridho, M. (2018). Urgensi Bimbingan Pra Nikah Terhadap Tingkat Penceraian. JIGC (Journal of Islamic Guidance and Counseling), 2(1), 63-78.

Rozikan, M. (2017). Transformasi Dakwah melalui Konseling Islami. INJECT (Interdisciplinary Journal of Communication), 2(1), 77-98.

Walgito, B. (2010). Bimbingan dan konseling (Studi dan Karir). Yogyakarta: CV Andi Offset.

Walgito, B. (2017). Bimbingan \& Konseling Perkahwinan. ANDI.

Willis, S. S. (2016). Konseling keluarga.

Wulan, R. (2021). Problematika Konselor dalam Pelaksanaan Bimbingan Konseling Perkawinan Dan Keluarga Kua Kecamatan Langsa Lama Kota Langsa. Jurnal Pasopati: Pengabdian Masyarakat Dan Inovasi Pengembangan Teknologi, 3(2).

\section{Competing interests:}

The authors declare that they have no significant competing financial, professional or personal interests that might have influenced the performance or presentation of the work described in this manuscript. 